\title{
Establishment of PMA Real-Time PCR Method to Detect Viable Cells of Listeria monocytogenes and Salmonella spp. in Milk and Dairy Products
}

\author{
Truc Ngoc Diem Do, Thuan Duc Lao and Thuy Ai Huyen Le* \\ Faculty of Biotechnology, Ho Chi Minh City Open University, Ho Chi Minh City (HCMC), \\ Thanh Pho Ho Chi Minh - 700000, Vietnam; thuy.lha@ou.edu.vn
}

\begin{abstract}
The infection with Salmonella spp., Listeria monocytogenes are the most contamination events in the milk and dairy products. There are many disadvantages of conventional culture-based methods, which are still recognized as the "gold standard" for identifying pathogenic bacteria. Thus, the aim of current study was to develop reliable and rapid method for the detection of bacteria causing foodborne. For the establishment of PMA Real-time PCR method for codetection of Salmonella spp., Listeria monocytogenes, bacteria strains, including Escherichia coli (ATCC 25922), Listeria monocytogenes (ATCC 19115; ATCC 19111), Salmonella enterica (ATCC 19115), Staphylococcus aureus (ATCC 25923), Vibrio parahaemolyticus (ATCC 17802), Shigella flexneri (ATCC 12022), Bacillus aureus (ATCC 11778) were enrolled into the establishment of current protocol. The concentration of PMA, primer concentration, probe concentration, and primer annealing temperature, specificity and sensitivity were evaluated. As the results, we successfully established the protocol of PMA Real-time PCR for co-detection of Salmonella spp. and Listeria monocytogenes on milk product. The concentration of PMA was determined as $50 \mu \mathrm{M}$. The sensitivity of established protocol were $10^{1} \mathrm{CFU} / \mathrm{ml}$ for detection of Salmonella spp., and $10^{2} \mathrm{CFU} / \mathrm{ml}$ for detection of Listeria monocytogenes. The current PMA Real-time PCR protocol was applied to detect the contamination of twenty local milk samples. No sample was co-contaminated with Salmonella spp. and Listeria monocytogenes. These results were similar to its performed by conventional culture-based methods. In summary, the current established PMA $(50 \mu \mathrm{M})$ Real-time PCR could be applied for the co-detection of Salmonella spp. and Listeria monocytogenes on milk and dairy food.
\end{abstract}

Keywords: Dairy Products, Listeria monocytogenes, PMA Real-time PCR, Salmonella spp.

\section{Introduction}

Milk and dairy products play an important role in human daily nutrition and diversifying the diet. However, milk and dairy products are rich in nutrients, delivering high-quality proteins, micronutrients, vitamins, and energy-containing fats, etc. However, it could be easily contaminated by spoilage microorganisms and foodborne pathogens from various sources, food processing as well as consumption. Salmonella spp., Listeria monocytogenes are the most frequently potential pathogens associated with milk and dairy products ${ }^{10}$. Salmonella spp. is reported to be the second most common bacterial cause of foodborne ${ }^{1}$. According to report of FAO and WHO, the infection of Listeria is a relatively are but serious disease with high fatality rates of $20 \%-30 \%$. Thus, it is essential

${ }^{*}$ Author for correspondence 
to develop reliable and rapid method for the detection of bacteria causing foodborne.

The conventional culture-based methods are still recognized as the "gold standard" for identifying pathogenic bacteria. However, this technique has many disadvantages, such as time-consuming, labor-intensities, and false-negative results due to nonculturable pathogens ${ }^{4,11}$. Thus a rapid, highly sensitive, and inexpensive detection technique is required. Real-time PCR technique have developed for routine analysis of pathogenic bacteria with many outstanding characteristics, such as faster and sensitivity was greater than conventional culture-based methods ${ }^{6}$. Especially, the real-time method could be applied to co-detection of multiple bacterial pathogens by a single of reaction conditions, still, limitation still exists. The false-positive results could be occurred because the real-time PCR method could not distinguish whether bacteria is alive or dead after the sterilization step of food processing due to the persistence of DNA after cell death ${ }^{2}$. To circumvent this problem, Propidium-Mono-Azide (PMA) was applied prior to PCR analysis to circumvent this problem, allowing discriminate alive/dead bacteria ${ }^{8}$. The dye of PMA can enter bacteria via the damaged cell membranes and covalently bind to genomic $\mathrm{DNA}^{7}$. As the results, the interaction between PMA and genomic DNA lead the inability to be amplified, thus preventing the detection of dead cells. PMA/Real-time PCR or PMA/ PCR has been applied to detection of Salmonella spp và Listeria monocytogenes in food ${ }^{5,7,9}$ successfully applied PMA Real-time PCR in detection of viable Salmonella Typhimurium in lettuce at as low as $10^{2} \mathrm{CFU} / \mathrm{mL}$ in pure culture and $10^{3} \mathrm{CFU} / \mathrm{g}$ in lettuce 5 . The sensitivity reached to $10^{1} \mathrm{CFU} / \mathrm{g}$ in lettuce within the 12 -h treatment with PMA. In the study of Yang et al. (2012) ${ }^{12}$ reported that PMA-mPCR (multiplex PCR) can simultaneously identify S. Typhimurium, Paratyphi B and Typhi in food with $1 \times 10^{6} \mathrm{CFU} / \mathrm{g}$ in spiked food products ${ }^{12}$. PMA realtime PCR was concluded as the suitable technique for the co-detection and co-quantification of viable pathogens, including Escherichia coli O157:H7, Salmonella and Listeria monocytogenes, in vegetable samples ${ }^{3}$. Although PMA real-time PCR or PMA PCR has been applied in detection of food borne pathogens from various sources, it is still scarce in milk and dairy product. Therefore, current study was carried out to establish the simple, efficient and economical PMA real-time PCR using FAM dyes-labeled probe for simultaneous detection and quantification Listeria monocytogenes và Salmonella spp. in milk and dairy products.

\section{Materials and Methods}

\subsection{Bacterial Strains, Growth Condition}

Bacterial strains: Escherichia coli (ATCC 25922), Listeria monocytogenes (ATCC 19115; ATCC 19111), Salmonella enterica (ATCC 19115), Staphylococcus aureus (ATCC 25923), Vibrio parahaemolyticus (ATCC 17802), Shigella flexneri (ATCC 12022), Bacillus aureus (ATCC 11778), were purchased from Microbiologics Inc. (USA), grown on XLD Agar and BHI Agar, respectively, at $37^{\circ} \mathrm{C}$ for $24 \mathrm{~h}$.

\subsection{DNA Isolation and Real-Time PCR Assay}

DNA was isolated from pure cultures and food samples by using the commercial method Top PURE Genomic DNA/ RNA extraction KIT (ABT, Vietnam) according to the guideline of manufacture. The primers and probes used in current were indicated in Table 1. For the detection and quantification Listeria monocytogenes và Salmonella spp., the protocol of real-time PCR assay was shown in Table 2.

Table 1. Probes and primers used in current study

\begin{tabular}{|l|l|}
\hline $\begin{array}{c}\text { Primers/ } \\
\text { Probes }\end{array}$ & \multicolumn{1}{|c|}{ Sequences (5'-3') } \\
\hline \multicolumn{2}{|c|}{ Salmonella spp. } \\
\hline Sal1598-F & AACGTGTTTCCGTGCGTAAT \\
\hline Sal1859-R & TCCATCAAATTAGCGGAGGC \\
\hline Sal1631-P & FAM-TGGAAGCGCTCGCATTGTGG-BHQ1 \\
\hline Listeria monocytogenes \\
\hline Lm835-F & AACTGGTTTCGTTAACGGTAAATACTTA \\
\hline Lm998-R & TAGGCGCAGGTGTAGTTGCT \\
\hline TxRd-P & $\begin{array}{l}\text { FAM-CTACTACTCAA } \\
\text { CAAGCTGCACCTGCTGC-BHQ1 }\end{array}$ \\
\hline Internal control \\
\hline dd-IAC-F & CTAACCTTCGTGATGAGCAATCG \\
\hline dd-IAC-R & GATCAGCTACGTGAGGTCCTAC \\
\hline dd-IAC-P & $\begin{array}{l}\text { Hex-AGCTAGTCGATGCACTCCAGTCCT } \\
\text { CCT-BHQ2 }\end{array}$ \\
\hline
\end{tabular}

${ }^{\star}$ Note: F: Forward primer, R: Reverse primer, P: Probe 
Table 2. Thermal assay for real-time PCR

\begin{tabular}{|l|c|c|}
\hline & Temperature $\left({ }^{\circ} \mathbf{C}\right)$ & Time (seconds) \\
\hline Step 1 & 95 & 300 \\
\hline \multirow{2}{*}{ Step 2 (x 40 cycles) } & 95 & 5 \\
\cline { 2 - 3 } & 60 & 30 \\
\hline
\end{tabular}

\subsection{Optimizing Primer Concentration, Probe Concentration, and Primer Annealing Temperature}

To verify that optimizing the concentration of primers and probes, assay performance was tested at the primer concentrations of 200, 400, $600 \mathrm{nM}$, combined with each probe concentration of $50,100,150 \mathrm{nM}$. The performance was carried on two concentrations, including $10^{6} \mathrm{CFU} / \mathrm{ml}$ and $10^{2} \mathrm{CFU} / \mathrm{ml}$, of Salmonella spp. (ATCC 19115) and Listeria monocytogenes (ATCC 19115) (Replication: three times).

For optimizing the primer annealing temperature, the following temperatures, including $55^{\circ} \mathrm{C}, 58^{\circ} \mathrm{C}, 60^{\circ} \mathrm{C}$, $62.5^{\circ} \mathrm{C}$ and $65^{\circ} \mathrm{C}$, were tested on two concentrations of $10^{6} \mathrm{CFU} / \mathrm{ml}$ and $10^{2} \mathrm{CFU} / \mathrm{ml}$, of Salmonella spp. (ATCC 19115) and Listeria monocytogenes (ATCC 19115) (Replication: three times).

\subsection{Evaluation of Primers and Probes Specificity and Sensitivity}

For the in vitro specificity validation, sets of primer and probe were tested by real-time PCR with target and non-target bacterial pathogens, including Escherichia coli (ATCC 25922), Staphylococus aureus (ATCC 25923), Shigella flexneri (ATCC 12022), Bacillus aureus (ATCC 11778), Vibrio parahaemolyticus (ATCC 17802), Salmonella spp. ATCC 19115; Liseria monocytogenes ATCC 19115.

For the in vitro sensitivity validation, mixture of 1 $\mathrm{mL}$ Liseria monocytogenes and $1 \mathrm{~mL}$ Salmonella spp. at following concentrations: $10^{3}, 10^{2}$ and $10^{1} \mathrm{CFU} / \mathrm{mL}$ were tested by real-time PCR.

\subsection{Inactivation of Bacterial Cells}

$10^{7}$ cells $/ \mathrm{mL}$ Salmonella spp. or Liseria monocytogenes was heated at $100^{\circ} \mathrm{C}, 5$ minutes or $90^{\circ} \mathrm{C}, 5$ minutes to validate the optimized temperature for inactivation of bacterial cells. The resulting heat-treated was cooled to room temperature, then culturing on XLD Agar (for Salmonella spp. cultivation), BHI Agar (for Liseria monocytogenes cultivation) and incubated in the dark at room temperature for 24-48 hours.

\subsection{Determination of the Optimized Concentration of PMA}

PMA was examined at two following concentrations: $25 \mu \mathrm{M}$ and $50 \mu \mathrm{M}$. Assay were carried on three groups of bacteria, including live bacteria, dead bacteria (heatkilled cells), and mixtures of live and dead bacteria by real-time PCR (treated/untreated with PMA). To investigate the optimal concentration of PMA, the value $\Delta \mathrm{Ct}$ was calculated according to $\Delta \mathrm{Ct}=\mathrm{Ct}(\mathrm{PMA})-\mathrm{Ct}(0)$. The optimal concentration of PMA was chosen by which the largest value of $\Delta \mathrm{Ct}$ had.

\subsection{PMA Real-Time PCR Assay on Bacteria Strains and Artificially Bacterial Pathogens-Contaminated Food Samples}

In order to determine whether PMA real-time PCR assay could specifically detect only alive bacterial cells but not dead bacterial cell (heat-killed cells), Salmonella spp. (ATCC 14028), or Listeria monocytogenes (ATCC 19111) at the concentration between $10^{1} \mathrm{CFU} / \mathrm{mL}$ to $10^{7} \mathrm{CFU} /$ $\mathrm{mL}$ was treated with $50 \mu \mathrm{M}$ PMA or untreated with PMA. Then, PMA-treated and PMA-untreated samples were processed identically for DNA extraction and real-time PCR.

The pasteurized milk samples, which were confirmed without contaminated by conventional culture-based method on XLD Agar and BHI Agar, were collected from local market. For artificial contamination, the pasteurized milk samples were artificially contaminated with Salmonella spp. (ATCC 14028), or Listeria monocytogenes (ATCC 19111) at the concentration of $10^{1} \mathrm{CFU} / \mathrm{ml}$ and $10^{7} \mathrm{CFU} / \mathrm{ml}$. Extracted genomic DNA from PMA treat and non-treated was analyzed using PMA real-time PCR. The value $\Delta \mathrm{Ct}$ was calculated according to $\Delta \mathrm{Ct}=$ $\mathrm{Ct}(\mathrm{PMA})-\mathrm{Ct}(0)$.

\subsection{PMA Real-Time PCR Assay on Local Milk Samples}

Total of 20 milk samples were tested in current study were analyzed for the presence and quantitative detection of Listeria monocytogenes và Salmonella spp. were collected in local market. The DNA extraction was performed 
according to the guideline of TopPURE ${ }^{\bullet}$ Genomic DNA extraction kit. The experiments were conducted by two independent assays: 1 . conventional culture-based methods; and 2. PMA real-time PCR assay (samples were treated and untreated with PMA $50 \mu \mathrm{M}$ ).

\section{Results and Discussion}

\subsection{Evaluation of Primer, Probe Concentration, and Primer Annealing Temperature}

There are no difference between the assay performances, which were tested at primer concentration of 200,400, $600 \mathrm{nM}$, combined with each probe concentration of 50, $100,150 \mathrm{nM}$. According to the primer concentration of $400 \mathrm{nM}$ combined with the probe concentration of 100 $\mathrm{nM}$, the Ct value of bacterial pathogens at density of $10^{6}$ $\mathrm{CFU} / \mathrm{ml}$ and $10^{2} \mathrm{CFU} / \mathrm{ml}$ were $24.89 \pm 0.06$ and $34.92 \pm$ 0.08 (for Salmonella spp.), and $24.01 \pm 0.05$ and $34.98 \pm$
1.16 (for Listeria monocytogenes), respectively (Figure 1). The optimal concentration of primers and probes were $400 \mathrm{nM}$ and $100 \mathrm{nM}$, respectively.

There are no difference between the assay performances, which were tested at annealing temperature of $55^{\circ} \mathrm{C}, 58^{\circ} \mathrm{C}, 60^{\circ} \mathrm{C}, 62.5^{\circ} \mathrm{C}$ and $65^{\circ} \mathrm{C}$. At the annealing temperature of $60^{\circ} \mathrm{C}$, the $\mathrm{Ct}$ value of bacterial pathogens at density of $10^{6} \mathrm{CFU} / \mathrm{ml}$ and $10^{2} \mathrm{CFU} / \mathrm{ml}$ were 24 and 34 (for Salmonella spp.), and 24 and 33 (for Listeria monocytogenes), respectively (Figure 2). The optimal annealing temperature was $60^{\circ} \mathrm{C}$.

\subsection{Evaluation of Specificity}

No target fluorescence signal and the $\mathrm{Ct}$ of 25 (IAC) were observed in the control group. Target signal was not observed in the samples of ATCC. Only positive controls (Salmonella spp. ATCC 19115; Liseria monocytogenes ATCC 19115) were positive. Thus, it could be concluded the primers and probes were specific to Salmonella spp

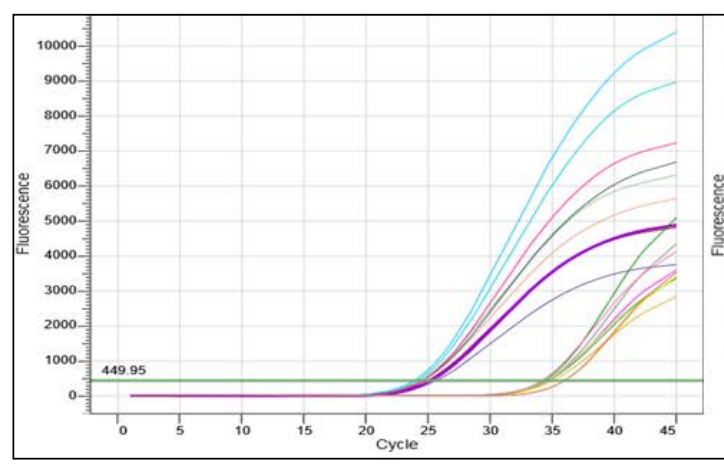

(A)

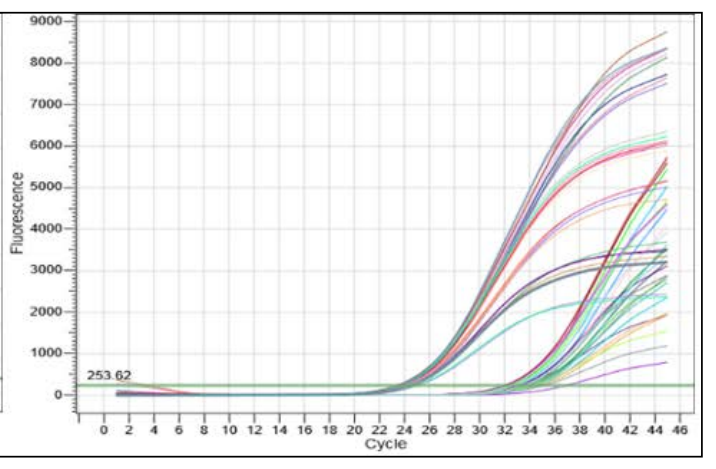

(B)

Figure 1. The amplification blot generated by $\mathrm{qPCR}$ at gradient concentration of primers and probesat bacterial pathogens density of $10^{6} \mathrm{CFU} / \mathrm{ml}$ and $10^{2} \mathrm{CFU} / \mathrm{ml}$. (A) Salmonella spp. (ATCC 14028); (B) Listeria monocytogenes (ATCC 19111).

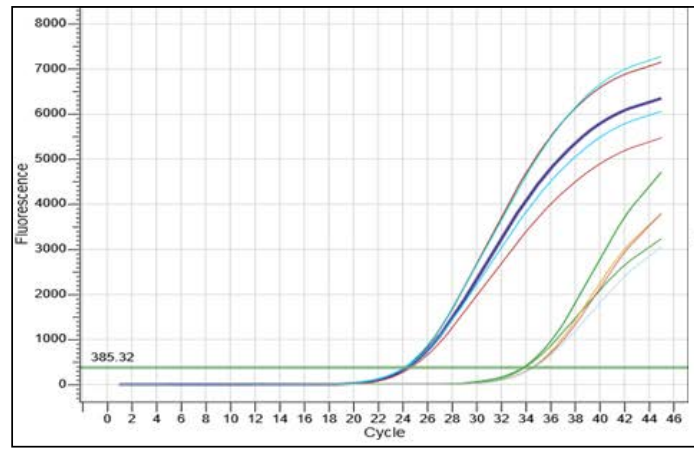

(A)

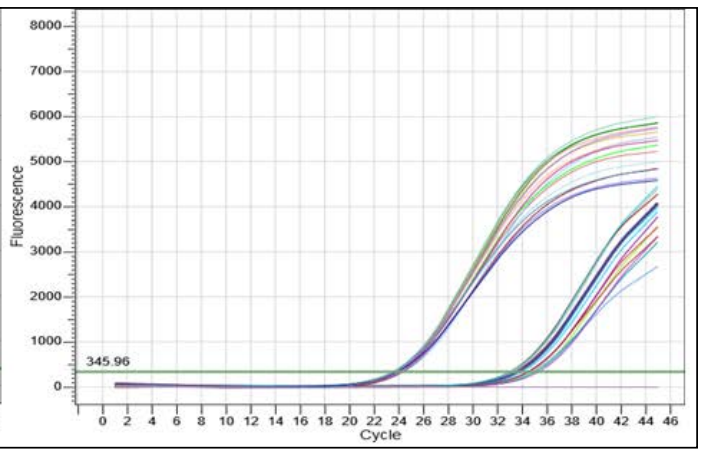

(B)

Figure 2. The amplification blot generated by qPCR at gradient annealing temperature at bacterial pathogens density of $10^{6}$ $\mathrm{CFU} / \mathrm{ml}$ and $10^{2} \mathrm{CFU} / \mathrm{ml}$. (A) Salmonella spp. (ATCC 14028); (B) Listeria monocytogenes (ATCC 19111). 
and Liseria monocytogenes, meant that did not pair with E. coli, S. aureus, V. parahaemolyticu, Shigella flexneri and Bacilus (Figure 3). Additionally, no cross-positive was observed in the strain of Salmonella spp. ATCC 19115; Liseria monocytogenes ATCC 19115.

\subsection{Evaluation of Sensitivity}

The result of evaluating sensitivity was performed in the sample of Salmonella spp. and artificial contaminated with Salmonella spp., were shown in Table 3 and Figure 4. As the result, the $\mathrm{Ct}$ of $37.11 \pm 0.45$ và $34.76 \pm 0.77$ were observed in in the concentration of $10^{1} \mathrm{CFU} / \mathrm{mlof}$ the sample of Salmonella spp. and artificial contaminated with Salmonella spp., respectively. The positive result of artificial contaminated with Salmonella spp. of concentration of $10^{1} \mathrm{CFU} / \mathrm{ml}$ was confirmed by conventional culturebased method on XLD Agar, as the result, it was similar to the PMA Real-time PCR method (Figure 4). Thus, the sensitivity of Salmonella spp. detection was $10^{1} \mathrm{CFU} / \mathrm{ml}$.

The result of evaluating sensitivity was performed in the sample of Liseria monocytogenes ATCC 19115 and artificial contaminated with Salmonella spp., were shown in Table 4 and Figure 5. As the result, the Ct of $37.17 \pm 0.41$ và $37.71 \pm 0.66$ were observed in the concentration of $10^{1} \mathrm{CFU} / \mathrm{ml}$ of the sample of Liseria monocytogenes and artificial contaminated with Liseria monocytogenes, respectively. The positive result of artificial contaminated with Salmonella spp. of concentration of $10^{1} \mathrm{CFU} / \mathrm{ml}$ was confirmed by conventional culture-based method on BHI Agar, as the result, it was similar to the PMA Realtime PCR method (Figure 5). Thus, the sensitivity of Salmonella spp. detection was $10^{1} \mathrm{CFU} / \mathrm{ml}$.

In the case of co-detection of artificial contaminated with Salmonella spp. and Liseria monocytogeneson the samples, the FAM green signal, which indicated to Liseria monocytogenes, and Texas red signal, which indicated to Salmonella spp., were observed (Figure 6). In detail, the $\mathrm{Ct}$ value were $32.13 ; 35.16$ and 38.78 in the concentration of $10^{3}, 10^{2}$ and $10^{1} \mathrm{CFU} / \mathrm{ml}$ of Salmonella spp., respectively; the $\mathrm{Ct}$ value were $31.87 ; 35.97$ and 37.15 in the concentration of $10^{3}, 10^{2}$ and $10^{1} \mathrm{CFU} / \mathrm{ml}$ of Liseria monocytogenes, respectively. Thus, the sensitivity of the codetection of Salmonella spp. and Liseria monocytogenes was $10^{1} \mathrm{CFU} / \mathrm{ml}$. This result was similar to Ding et al. (2017).

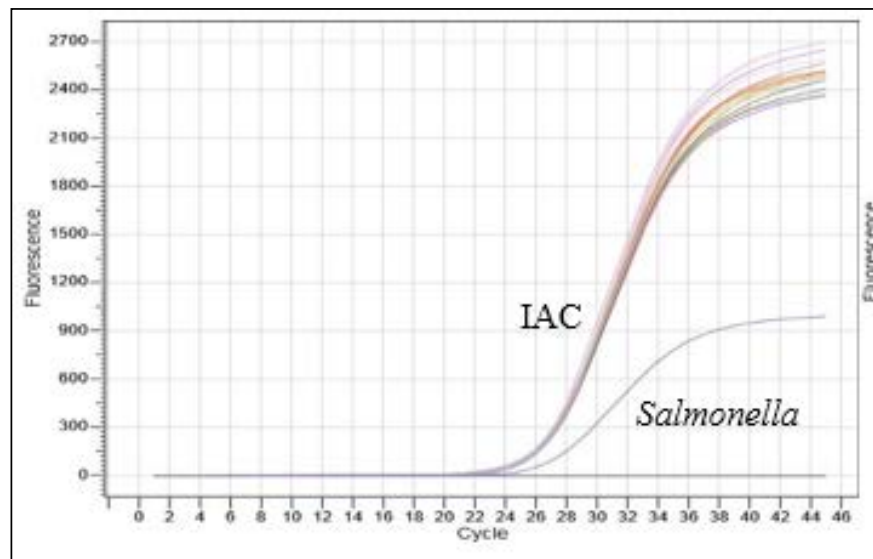

(A)

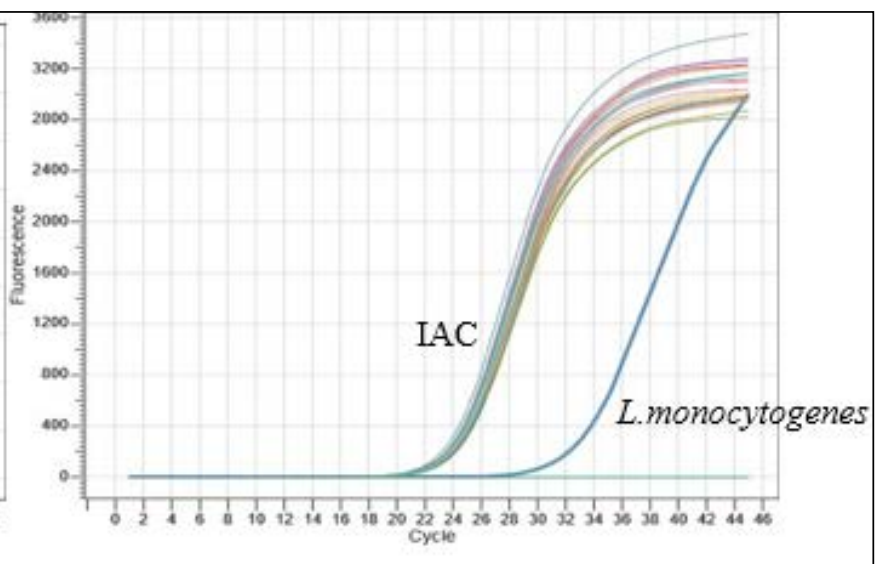

(B)

Figure 3. The amplification blot generated by qPCR at evaluation of the primers and probes' specificity. (A) Salmonella spp. (ATCC 14028); (B) Listeria monocytogenes (ATCC 19111).

Table 3. Results of PMA Real-time PCR on the samples of Salmonella spp. ATCC14028 and artificial contaminated samples

\begin{tabular}{|c|c|c|c|c|c|c|}
\hline \multicolumn{7}{|c|}{ Salmonella spp. (CFU/ml) } \\
\hline $\mathbf{1 0}^{7}$ & $\mathbf{1 0}^{6}$ & $\mathbf{1 0}^{5}$ & $\mathbf{1 0}^{4}$ & $\mathbf{1 0}^{3}$ & $\mathbf{1 0}^{2}$ & $\mathbf{1 0}^{1}$ \\
\hline $18.88 \pm 0.9$ & $19.08 \pm 0.47$ & $22.91 \pm 0.47$ & $26.71 \pm 0.44$ & $29.52 \pm 0.48$ & $33.5 \pm 0.54$ & $37.11 \pm 0.45$ \\
\hline $19.01 \pm 0.3$ & $21.13 \pm 0.6$ & $24.29 \pm 0.6$ & $26.89 \pm 0.55$ & $29.3 \pm 0.63$ & $31.24 \pm 0.59$ & $34.76 \pm 0.77$ \\
\hline
\end{tabular}




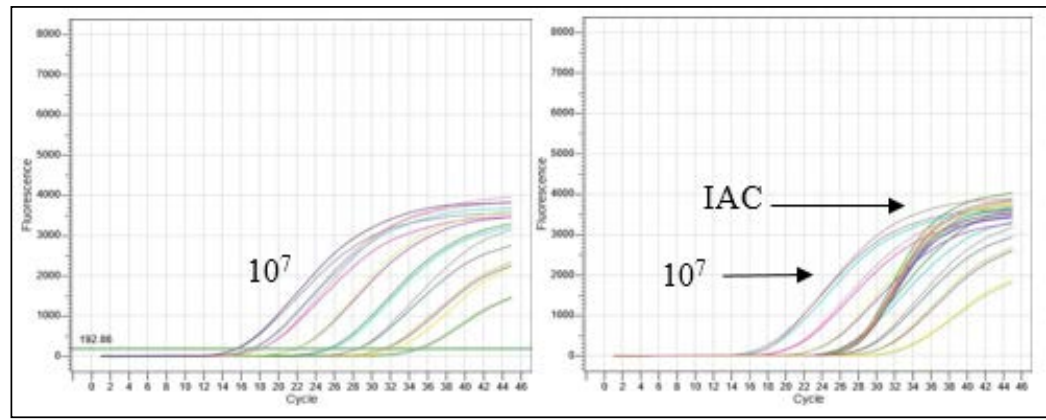

(A)

(B)
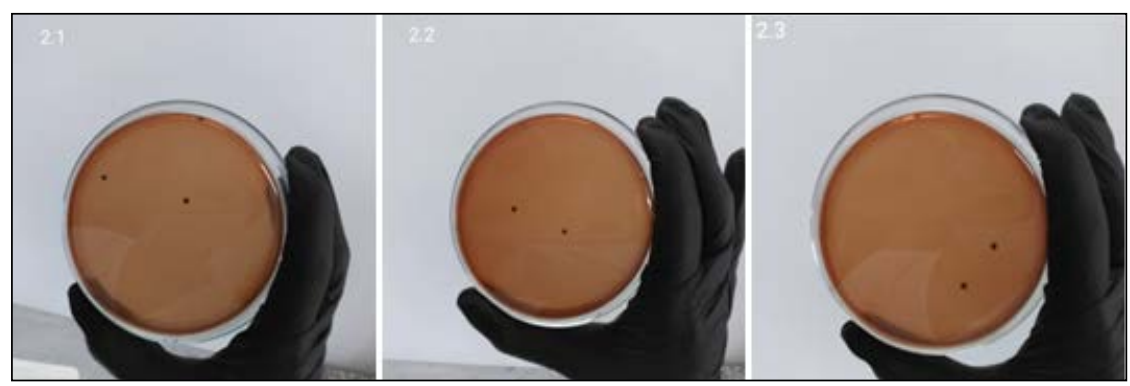

(C)

Figure 4. The amplification blot generated by Real-time qPCR at (A) Salmonella spp. ATCC14028; (B) artificial contaminated with Salmonella spp.; and (C) The conventional culture-based method on XLD Agar result of $10^{1} \mathrm{CFU} / \mathrm{ml}$ of artificial contaminated with Salmonella spp.

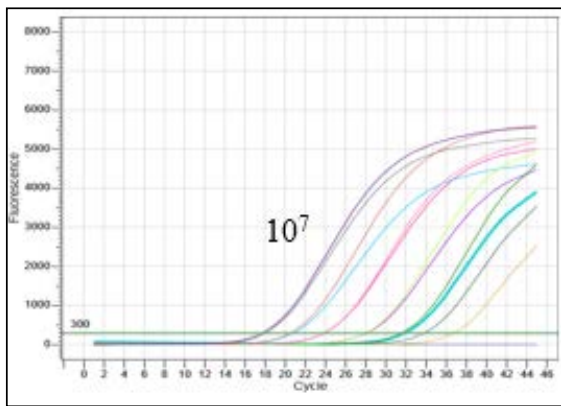

(A)

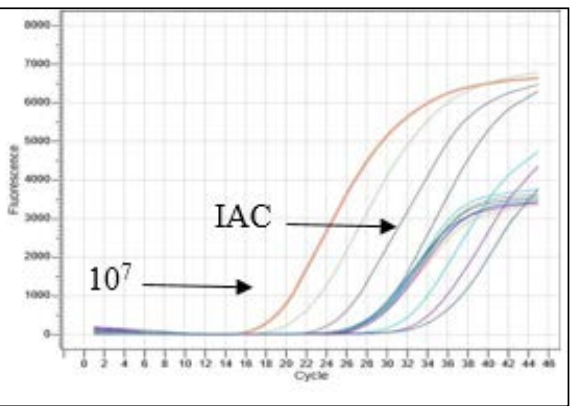

(B)

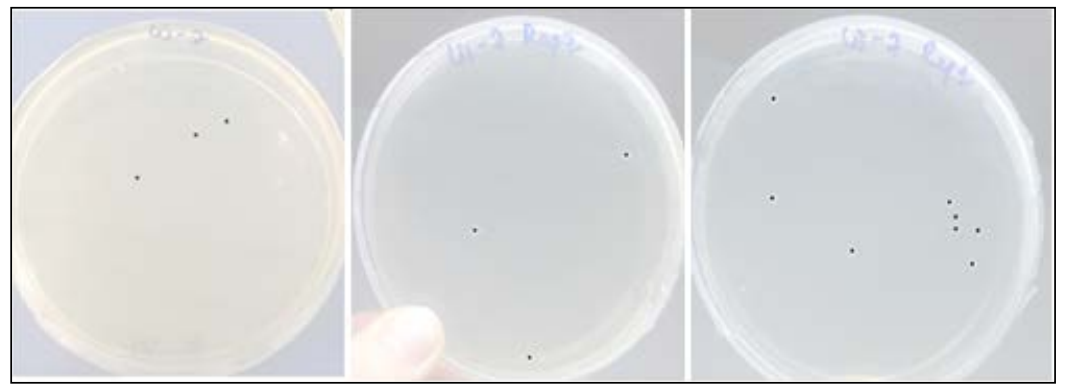

(C)

Figure 5. The amplification blot generated by Real-time qPCR at (A) Liseria monocytogenes ATCC 19115; (B) artificial contaminated with Liseria monocytogenes; and (C) The conventional culture-based method on BHI Agar result of $10^{1} \mathrm{CFU} / \mathrm{ml}$ of artificial contaminated with Liseria monocytogenes. 


\section{Establishment of PMA Real- Time PCR to Co-Detect Salmonella spp. and Liseria monocytogenes on Milk}

\subsection{Evaluation of the Heat Inactivation of Bacterial Cells}

The heat-treated Salmonella spp. or Liseria monocytogenes was incubated in the dark at room temperature for 24-48 hours. As the results, $90^{\circ} \mathrm{C}$-treated Liseria monocytogenes formed colonies in culturing BHI Agar. $90^{\circ} \mathrm{C}$-treated or $100^{\circ} \mathrm{C}$-treated Salmonella spp. for 5 minutes, and $100^{\circ} \mathrm{C}$-treared Liseria monocytogenes did not grow in the culturing Agar (Figure 7). Thus, the temperature $100^{\circ} \mathrm{C}$ was used for inactivation of both Salmonella spp. and Liseria monocytogenes.

\subsection{Evaluation of the Concentration of PMA}

Two concentrations of PMA $25 \mu \mathrm{M}$ and $50 \mu \mathrm{M}$ were examined at three groups of bacteria, including live

Table 4. Results of PMA real-time PCR on the samples of Salmonella spp. ATCC14028 and artificial contaminated samples

\begin{tabular}{|c|c|c|c|c|c|c|}
\hline \multicolumn{7}{|c|}{ L. monocytogenes (CFU/ml) } \\
\hline $\mathbf{1 0}^{7}$ & $\mathbf{1 0}^{6}$ & $\mathbf{1 0}^{5}$ & $\mathbf{1 0}^{4}$ & $\mathbf{1 0}^{3}$ & $\mathbf{1 0}^{2}$ & $\mathbf{1 0}^{1}$ \\
\hline $18.39 \pm 0.28$ & $21.2 \pm 0.62$ & $24.25 \pm 0.77$ & $28,51 \pm 0.76$ & $32.3 \pm 0.45$ & $34,2 \pm 0.49$ & $37.17 \pm 0.41$ \\
\hline $19.71 \pm 0.61$ & $22.54 \pm 0.15$ & $26.62 \pm 0.59$ & $29,45 \pm 0.37$ & $32.56 \pm 0.53$ & $34,03 \pm 0.58$ & $37.71 \pm 0.66$ \\
\hline
\end{tabular}

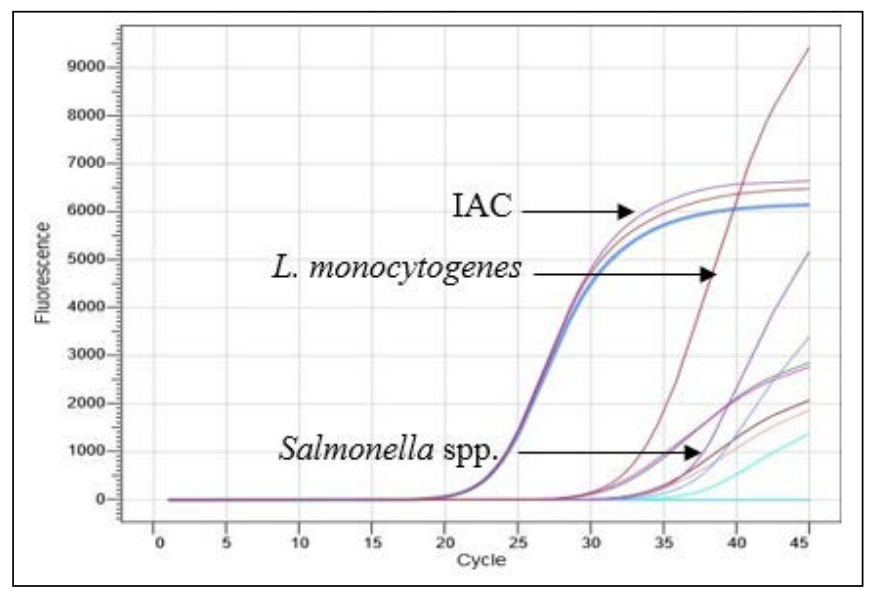

Figure 6. The amplification blot generated by real-time qPCR at the co-detection assay of artificial contaminated with Salmonella spp. and Liseria monocytogenes on the samples.

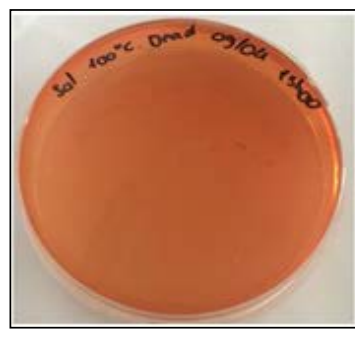

(A)

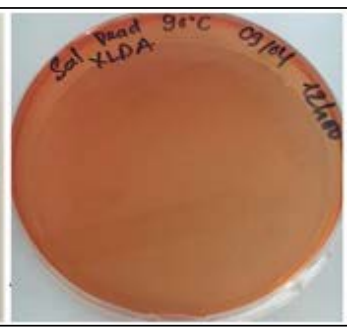

(B)

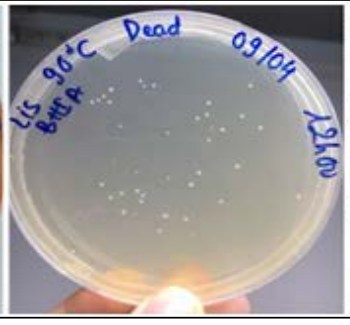

(C)

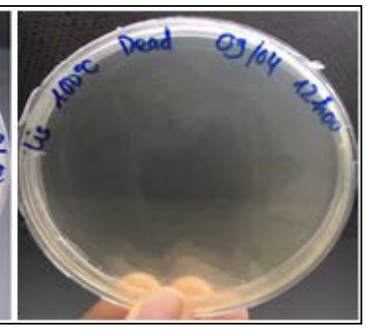

(D)

Figure 7. The cultivation of heat inactivation of bacterial cells cultured based on conventional culture-based method on XLD Agar and BHI Agar. (A) $100^{\circ} \mathrm{C}$-treated Salmonella spp.; (B) $90^{\circ} \mathrm{C}$-treated Salmonella spp.; (C) $90^{\circ} \mathrm{C}$-treated Liseria monocytogenes; and (D) $100^{\circ} \mathrm{C}$-treated Liseria monocytogenes. 
bacteria, dead bacteria (heat-killed cells), and mixtures of live and dead bacteria by real-time PCR (treated/ untreated with PMA). As the results, both treated and untreated group gave the $\Delta \mathrm{Ct}<1$ in the group of live bacteria and mixtures of live and dead bacteria. In the group of dead bacteria, the treated and untreated group of the concentration of $50 \mu \mathrm{M}$ PMA gave the $\Delta \mathrm{Ct}$ ( $>9$ : Salmonella spp.; $>7$ : Liseria monocytogenes), which was larger than the $\Delta \mathrm{Ct}(>8$ : Salmonella spp.; $>5$ : Liseria monocytogenes) given by the concentration of $25 \mu \mathrm{M}$ PMA (Table 5). Thus, it could be concluded that the

Table 5. Results of the optimal concentration of PMA carried on three groups of bacteria

\begin{tabular}{|c|c|c|c|c|c|}
\hline & $\mathbf{0}$ & 25 & 50 & $\Delta \mathrm{Ct}(1)$ & $\Delta \mathrm{Ct}(2)$ \\
\hline \multicolumn{6}{|l|}{ Live } \\
\hline Salmonella spp. & 16.41 & 16.62 & 16.17 & 0.21 & -0.24 \\
\hline $\begin{array}{l}\text { Liseria } \\
\text { monocytogenes }\end{array}$ & 19.93 & 21.26 & 21.29 & 1,33 & 1.36 \\
\hline \multicolumn{6}{|l|}{ Dead } \\
\hline Salmonella spp. & 15.16 & 23.22 & 24.18 & 8.06 & 9.02 \\
\hline $\begin{array}{l}\text { Liseria } \\
\text { monocytogenes }\end{array}$ & 21.26 & 26.63 & 28.63 & 5.37 & 7.37 \\
\hline \multicolumn{6}{|l|}{ Mix } \\
\hline Salmonella spp. & 15.88 & 15.57 & 16.82 & -0.31 & 0.94 \\
\hline $\begin{array}{l}\text { Liseria } \\
\text { monocytogenes }\end{array}$ & 22.39 & 22.69 & 23.38 & 0.30 & 0.99 \\
\hline
\end{tabular}

${ }^{*}$ Note: $\Delta \operatorname{Ct}(1)=\operatorname{Ct}(25 \mu \mathrm{M})-\operatorname{Ct}(0 \mu \mathrm{M}) ; \Delta \operatorname{Ct}(2)=\operatorname{Ct}(50$ $\mu \mathrm{M})-\mathrm{Ct}(0 \mu \mathrm{M})$ optimized concentration of PMA was $50 \mu \mathrm{M}$, which could be used for distinguishing the dead and live bacteria.

\subsection{Establishing PMA Real-Time PCR Assay}

Results of PMA Real-time PCR assay on Salmonella spp., ATCC 19115 and L. monocytogenes ATCC 19115 was reported in Table 6 and Figure 8. Based on the value of $\Delta \mathrm{Ct}(\Delta \mathrm{Ct}<1)$, it indicated that PMA did not effect on the genetic materials of live bacteria. The sensitivity of current protocol was $10^{1} \mathrm{CFU} / \mathrm{ml}$ and PMA concentration was 50 $\mathrm{mM}$. The sensitivity of the current protocol was higher than that of some previous studies ${ }^{3,5,12}$.

\subsection{Analysis of the Ability of PMA Real- Time PCR to Distinguish Live and Dead Bacteria}

Concerning to the Salmonella spp. (live) and $L$. monocytogenes (Live), before and after PMA-treated sample gave the $\Delta \mathrm{Ct}$ value $<1 \mathrm{Ct}$. these results indicated that PMA do not affect the live bacteria. In particular, no fluorescent signal was observed on the sample of $L$. monocytogenes with the concentration of $10^{1} \mathrm{CFU} / \mathrm{ml}$ (Table 7 and Figure 9). In the sample of Salmonella spp. (Dead) and L. monocytogenes (Dead), before and after PMA-treated sample gave the $\Delta \mathrm{Ct}>8$ and $>6$ (Table 7 and Figure 9). In the sample with the low concentration $\left(<10^{4}\right.$ $\mathrm{CFU} / \mathrm{ml}$ ), no fluorescent signals were after PMA-treated samples. These result indicated that PMA completely inhibited the Real-time PCR assay.

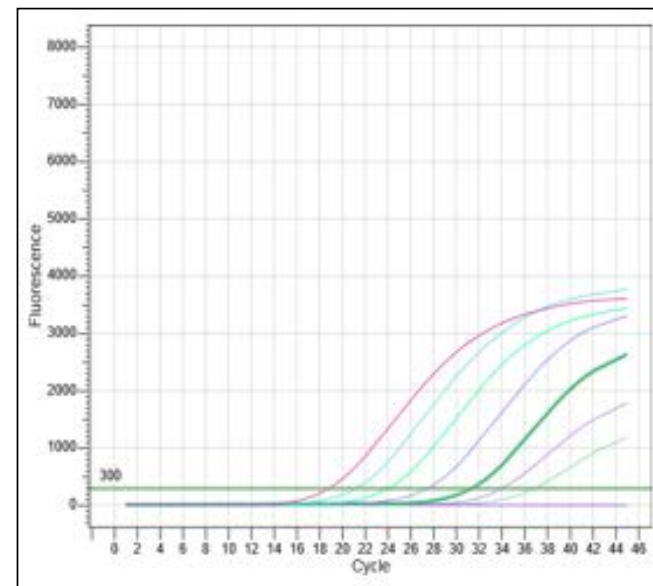

(A)

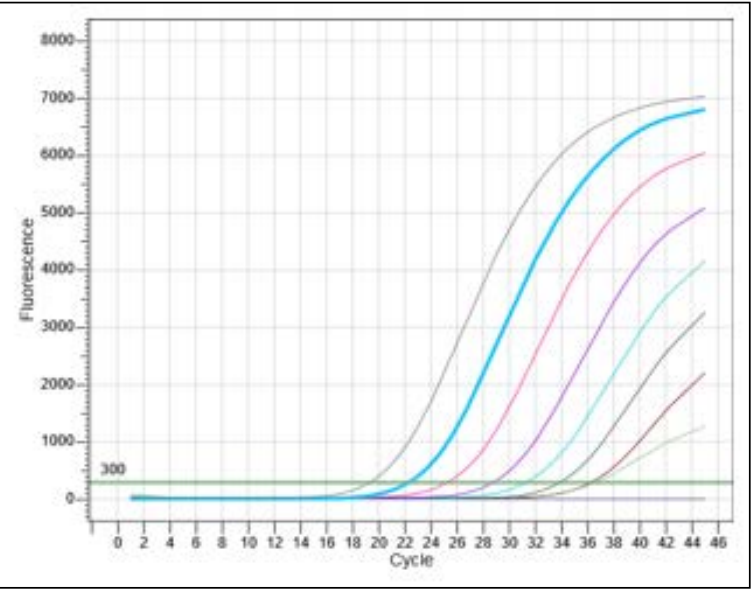

(B)

Figure 8. The amplification blot generated by PMA real-time qPCR at gradient concentration from $10^{7} \mathrm{CFU} / \mathrm{mL}$ to $10^{1} \mathrm{CFU} /$ $\mathrm{mL}$ of (A) Salmonella spp.; and (B) L. monocytogenes. 
Table 6. Results of real-time PCR on the sample of Salmonella spp., and L. monocytogenes with before and after treated with PMA

\begin{tabular}{|c|c|c|c|c|c|c|c|c|}
\hline & & $10^{7}$ & $10^{6}$ & $10^{5}$ & $10^{4}$ & $10^{3}$ & $10^{2}$ & $10^{1}$ \\
\hline \multicolumn{9}{|c|}{ Salmonella spp., $(\Delta \mathrm{Ct}<1)$} \\
\hline \multirow{2}{*}{ PMA (nM) } & 0 & 18.39 & 22.3 & 25.97 & 29.28 & 32.34 & 35.66 & 37.31 \\
\hline & 50 & 19.16 & 21.54 & 24.41 & 27.87 & 31.7 & 34.36 & 37.14 \\
\hline \multicolumn{9}{|c|}{ L. monocytogenes, $(\Delta \mathrm{Ct}<1)$} \\
\hline \multirow{2}{*}{ PMA (mM) } & 0 & 18.13 & 20.94 & 24.29 & 28.45 & 31.99 & 34.12 & 37.17 \\
\hline & 50 & 19.71 & 22.69 & 25.67 & 29.12 & 31.27 & 34.27 & 36.63 \\
\hline
\end{tabular}

Table 7. Results of real-time PCR on the sample of Salmonella spp., (live, dead) and L. monocytogenes (live, dead) with before and after treated with PMA

\begin{tabular}{|c|c|c|c|c|c|c|c|c|}
\hline & & $10^{7}$ & $10^{6}$ & $10^{5}$ & $10^{4}$ & $10^{3}$ & $10^{2}$ & $10^{1}$ \\
\hline \multicolumn{9}{|c|}{ Salmonella spp., (live) $(\Delta \mathrm{Ct}<1)$} \\
\hline \multirow{2}{*}{ PMA (nM) } & 0 & 15.54 & 19.62 & 22.23 & 25.95 & 29.26 & 32.36 & 36.36 \\
\hline & 50 & 17.40 & 20.95 & 24.08 & 27.55 & 31.08 & 34.49 & 37.85 \\
\hline \multicolumn{9}{|c|}{ Salmonella spp., (dead) $(\Delta \mathrm{Ct}>8-10)$} \\
\hline \multirow{2}{*}{ PMA (mM) } & 0 & 16.03 & 19.32 & 22.50 & 25.90 & 29.35 & 32.09 & 34.81 \\
\hline & 50 & 30.97 & 27.41 & 30.73 & 34.94 & $(-)$ & $(-)$ & $(-)$ \\
\hline \multicolumn{9}{|c|}{ L. monocytogenes (live) $(\Delta \mathrm{Ct}<1)$} \\
\hline \multirow{2}{*}{ PMA (mM) } & 0 & 17.01 & 20.59 & 23.69 & 27.02 & 29.85 & 32.68 & 35.24 \\
\hline & 50 & 17.9 & 21.51 & 24.76 & 28.23 & 31.67 & 34.47 & $(-)$ \\
\hline \multicolumn{9}{|c|}{ L. monocytogenes (live) $(\Delta \mathrm{Ct}>6-10)$} \\
\hline \multirow{2}{*}{ PMA (mM) } & 0 & 20.10 & 23.64 & 26.73 & 29.92 & 33.32 & 32.39 & $(-)$ \\
\hline & 50 & 30.66 & 35.53 & 34.20 & 35.58 & $(-)$ & $(-)$ & $(-)$ \\
\hline
\end{tabular}

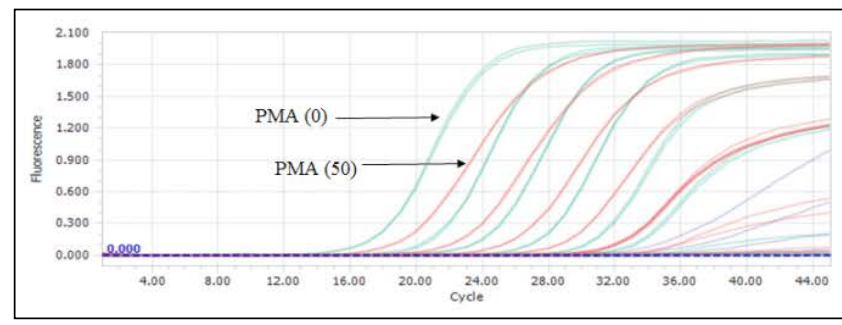

(A)

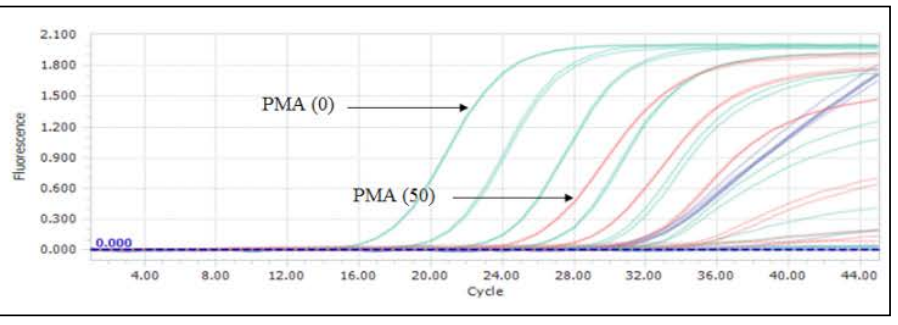

(B)

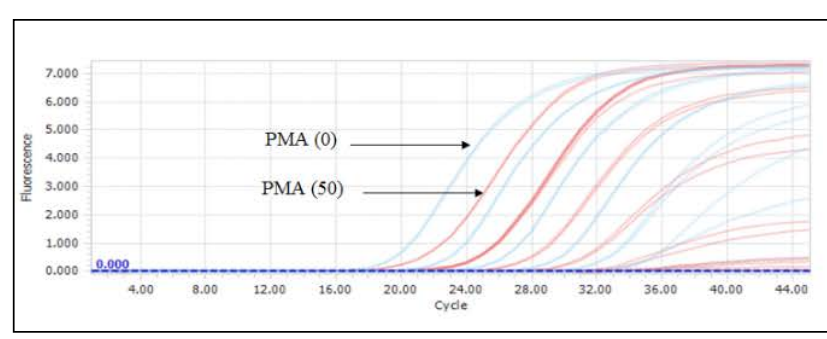

(C)

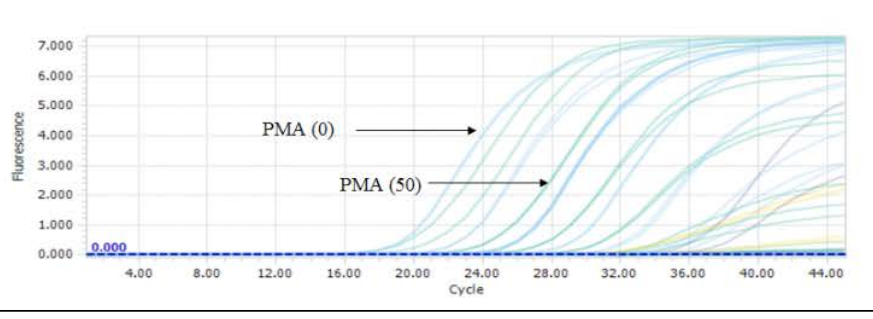

(D)

Figure 9. The amplification blot generated by PMA Real-time qPCR at gradient concentration from $10^{7} \mathrm{CFU} / \mathrm{mL}$ to $10^{1} \mathrm{CFU} /$ $\mathrm{mL}$ of (A) Salmonella spp. (live); (B) Salmonella spp. (dead); (C) L. monocytogenes (live); and (D) L. monocytogenes (dead). 


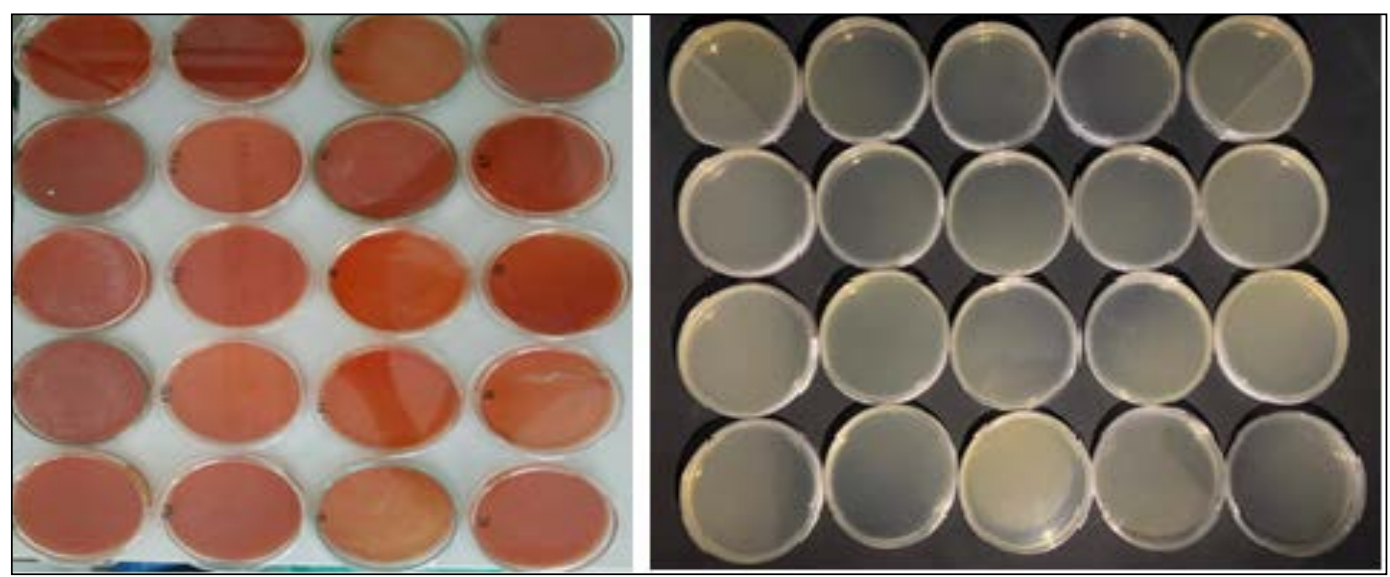

Figure 10. No colonies were observed on twenty local milk samples.

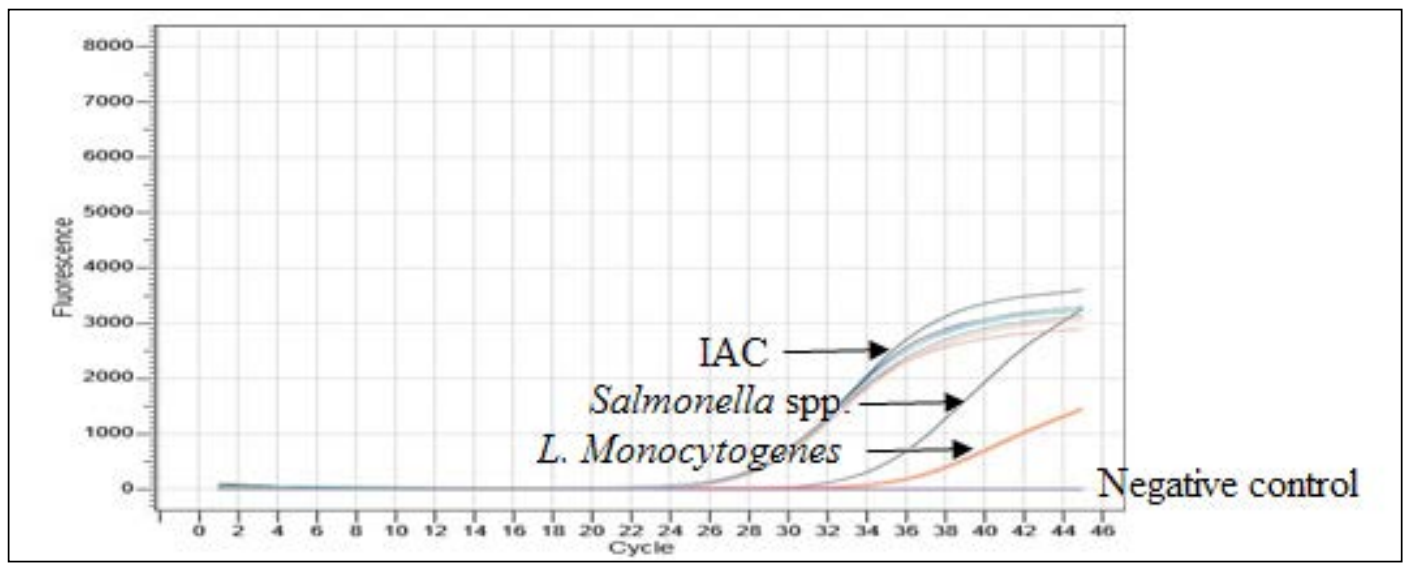

Figure 11. The amplification blot generated by PMA real-time qPCR at local samples.

Implementation on the artificial contaminated pasteurized milk, the results indicated that established PMA Real-time PCR could detect the Salmonella spp. Within the concentration of $10^{1} \mathrm{CFU} / \mathrm{ml}$ and $L$. monocytogenes within the concentration of $10^{2} \mathrm{CFU} /$ $\mathrm{ml}$. These results were the sensitivity of current assay was similar to the study of Li et al. (2013), and higher than the study of Liang et al. $(2011)^{5}$ and Yang et al. $(2012)^{12}$.

\subsection{PMA Real-Time PCR Assay on Local Milk Samples}

At first, twenty milk samples were collected in the local market then the samples were cultured on XLD Agar and BHI Agar to confirm whether or not contaminated with Salmonella spp. and L. monocytogenes. As the results, no colonies were observed on 20 local milk samples (Figure
10). It indicated that all of 20 samples did not contaminate with Salmonella spp. and L. monocytogenes.

Then, the PMA Real-time PCR assay was applied to detect the contamination of twenty local milk samples. As the results, the fluorescent signals were observed in the positive group, and no the fluorescent signals were observed in the positive group. Concerning to twenty local samples, no signals were records, meanwhile the signals of IAC were recorded at the Ct of 25 (Figure 11). Thus, it indicated that no contamination of Salmonella spp. and L. monocytogenes were detected in local samples. The results of PMA Real-time PCR were similar to its performed by conventional culture-based methods.

According to economic viability, this in-house multiple kit for co-detection of Salmonella spp. and Listeria monocytogenes on milk product will be at the price of 3.0 USD per test. Therefore, it facilitates the application 
for the detection of these pathogens in the dairy products in developing countries.

\section{Conclusion}

We successfully established the protocol of PMA $(50 \mu \mathrm{M})$ Real-time PCR for co-detection of Salmonella spp. and Listeria monocytogenes on milk product. The sensitivity of established protocol was $10^{1} \mathrm{CFU} / \mathrm{ml}$ for detection of Salmonella spp., and $10^{2} \mathrm{CFU} / \mathrm{ml}$ for detection of Listeria monocytogenes. The current PMA Real-time PCR protocol was applied to detect the contamination of twenty local milk samples. As the result, no sample was co-contaminated with Salmonella spp. and Listeria monocytogenes. These results were similar to its performed by conventional culture-based methods. In summary, the current established PMA $(50 \mu \mathrm{M})$ Real-time PCR could be applied for the co-detection of Salmonella spp. and Listeria monocytogenes on milk and dairy food.

\section{Declaration of Interest}

None

\section{Reference}

1. Aarestrup FM, Hendriksen RS, Lockett J, Gay K, Teates K, McDermott PF, White DG, Hasman H, Sørensen G, Bangtrakulnonth A, Pornreongwong S, Pulsrikarn C, Angulo FJ, Gerner-Smidt P. International spread of multidrug-resistant Salmonella Schwarzengrund in food products. Emerg Infect Dis. 2007; 13(5):726-731. https://doi.org/10.3201/eid1305.061489. PMid:17553251 PMCid:PMC2738437.

2. Cangelosi GA, Meschke JS. Dead or alive: Molecular assessment of microbial viability. Appl Environ Microbiol. 2014; 80(19):5884-5891. https://doi.org/10.1128/AEM.01763-14. PMid:25038100 PMCid:PMC4178667.

3. Elizaquível P, Sánchez G, Aznar R. Quantitative detection of viable foodborne E. coli O157:H7, Listeria monocytogenes and Salmonella in fresh-cut vegetables combining propidiummonoazide and real-time PCR. Food Control. 2012; 25(2):704-708. https://doi.org/10.1016/j.foodcont.2011.12.003.

4. Law JW, Ab Mutalib NS, Chan KG, Lee LH. Rapid methods for the detection of foodborne bacterial pathogens: principles, applications, advantages and limitations. Front Microbiol. 2015; 5:770. https://doi.org/10.3389/ fmicb.2014.00770. PMid:25628612 PMCid:PMC4290631.

5. Liang N, Dong J, Luo L, Li Y. Detection of viable Salmonella in lettuce by propidiummonoazide real-time PCR. J Food Sci. 2011; 76(4):M234-M237. https://doi.org/10.1111/j.1750-3841.2011.02123.x. PMid:22417362.

6. Liu Y, Cao Y, Wang T, Dong Q, Li J, Niu C. Detection of 12 common food-borne bacterial pathogens by TaqMan real-time PCR using a single set of reaction conditions. Front Microbiol. 2019; 10:222. https://doi.org/10.3389/ fmicb.2019.00222. PMid:30814987 PMCid:PMC6381072.

7. Ma Y, Deng Y, Xu Z, Liu J, Dong J, Yin H, Yu J, Chang Z, Wang D. Development of a propidiummonoazide-polymerase chain reaction assay for detection of viable Lactobacillus brevis in beer. Braz J Microbiol. 2017; 48(4):740-746. https://doi.org/10.1016/j.bjm.2016.11.012. PMid:28633981 PMCid:PMC5628306.

8. Nocker A, Camper AK. Selective removal of DNA from dead cells of mixed bacterial communities by use of ethidium monoazide. Appl Environ Microbiol. 2006; 72(3):1997-2004. https://doi.org/10.1128/AEM.72.3.19972004.2006. PMid:16517648 PMCid:PMC1393219.

9. Seinige D, Krischek C, Klein G, Kehrenberg C. Comparative analysis and limitations of ethidium monoazide and propidiummonoazide treatments for the differentiation of viable and nonviable campylobacter cells. Appl Environ Microbiol. 2014; 80(7):2186-2192. https://doi.org/10.1128/ AEM.03962-13. PMid:24487529 PMCid:PMC3993131.

10. Shamloo E, Hosseini H, Abdi Moghadam Z, Halberg Larsen M, Haslberger A, Alebouyeh M. Importance of Listeria monocytogenes in food safety: A review of its prevalence, detection, and antibiotic resistance. Iran J Vet Res. 2019; 20(4):241-254. https://doi.org/10.26656/fr.2017.4(1).155.

11. Wiemer D, Loderstaedt $U$, von Wulffen $H$, Priesnitz S, Fischer M, Tannich E, Hagen RM. Real-time multiplex PCR for simultaneous detection of Campylobacter jejuni, Salmonella, Shigella and Yersinia species in fecal samples. Int J Med Microbiol. 2011; 301(7):577-584. https://doi. org/10.1016/j.ijmm.2011.06.001. PMid:21855409.

12. Yang Y, Wan C, Xu H, Lai W, Xiong Y, Xu F, You X, Xu H, Aguilar ZP, Sun J, Wei H. Development of a multiplexed PCR assay combined with propidiummonoazide treatment for rapid and accurate detection and identification of three viable Salmonella entericaserovars. Food Control. 2012; 28(2):456-462. https://doi.org/10.1016/j. foodcont.2012.05.061. 